\title{
The Effect of Organic Waste and Synthetic Conditioner Applications on Consistency Limits
}

\author{
Zerrin CIVELEK ${ }^{1 *}$ \\ Nutullah ÖZDEMiR' \\ 'Ondokuz Mayıs University, Department of Soil Science and Plant Nutrition, Samsun, Turkey
}

\author{
*Corresponding author e-mail : zrrnCVLK@outlook.com \\ Received : 17.07.2021 \\ Accepted : 16.08.2021 \\ DOI:10.21657/topraksu. 972704
}

\begin{abstract}
This study was carried out to determine the effects of wheat straw (WS), hazelnut husk $(H H)$, humic acid (HA) and polyacrylamide (PAM) treatments on consistency limits (liquid limit (LL), plastic limit (PL), plasticity index (PI)) in two soils with sandy loam and clayey loam in texture. Soil samples used in the study were taken from two different areas of land $(0-20 \mathrm{~cm})$ from Samsun province's Bafra district. WS (0, 2\%, 4\%), HH (0, 2\%, 4\%), HA (0, 200 and 1000 ppm) and PAM (0, 30 and 90 ppm) were used in this study that was conducted in a split plots experimental design with three replications. According to the results; it was determined that the liquid limit, plastic limit and plasticity index values increased with the application of organic and synthetic conditioners in both soil texture, and the effect was realized as WS $>\mathrm{HH}>\mathrm{HA}>\mathrm{PAM}$. It was observed that the highest dose application was the more effective in both soil texture, except for PAM.
\end{abstract}

Keywords: Hazelnut husk, humic acid, liquid limit, plastic limit

\section{Organik Atık ve Sentetik Düzenleyici Uygulamalarının Kıvam Limitleri Üzerine Etkisi}

\section{Öz}

Bu araștırma, kumlu tın ve killi tın tekstüre sahip iki toprakta buğday samanı (WS), fındık zurufu $(\mathrm{HH})$, hümik asit (HA) ve poliakrilamid (PAM) uygulamalarının kIvam limitleri (likit limit (LL), plastik limit $(\mathrm{PL})$, plastiklik indeksi (PI)) üzerine etkilerini belirlemek üzere yürütülmüștür. Çalıșmada kullanılan toprak örnekleri, Samsun ili Bafra ilçesinde tarla tarımı yapılan iki farklı araziden $(0-20 \mathrm{~cm})$ alınmıștır. Bölünmüș parseller deneme deseninde yürütülen çalıșmada buğday samanı $(0, \% 2, \% 4)$, fındık zurufu $(0, \% 2, \% 4)$, hümik asit (0, 200 ve 1000 ppm) ve PAM (0, 30 ve 90 ppm) topraklara üç tekerrürlü olarak uygulanmıștır. Sonuç olarak, likit limit, plastik limit ve plastiklik indeksi değerlerinin her iki toprak tekstüründe de organik ve sentetik düzenleyici uygulaması ile arttığı, etkininin WS>HH>HA>PAM șeklinde gerçekleștiği tespit edilmiștir. Her iki toprak tekstürün de PAM hariç en yüksek doz uygulamasının daha etkili olduğu görülmüștür.

Anahtar kelimeler: Fındık zurufu, hümik asit, likit limit, plastik limit

\section{INTRODUCTION}

The liquid limit is defined as limit water content values when a dry soil flows under the influence of a small external force due to the increasing water content, while the plastic limit is defined as the water content values when the soil starts to crumble while losing its water. The numerical difference between the liquid limit and the plastic limit is called the plasticity index (Dexter and Bird, 2001; Gülser and Candemir, 2006). 
The liquid limit (LL), plastic limit (PL), and plasticity index (PI) are defined as consistency limits and are important parameters in the evaluation of some properties of soil when used for agricultural or engineering purposes. These parameters gain value depending on the dominant clay mineral type of the soil, the clay content, the type of exchangeable cations, and the amount of organic matter (Odell et al., 1960; Farrar and Coleman, 1967).

Canbolat and Öztaș (1997), in a study in which they examined the relationships between soil consistency limits and some physicochemical properties, revealed significantly positive correlations between the clay content, organic matter content, lime content, cation exchange capacity and the liquid limit and plastic limit values, and significantly negative correlations with sand content. Yakupoğlu and Özdemir (2006), as a result of the study in which they applied biosolids and tea waste to soils eroded at different levels, reported that the additions of organic material significantly increase the liquid limit (LL) and plastic limit (PL) values of the soils, and such increase depends on the increased erosion levels, the type of waste and the applied dose for the liquid limit, and the type of clay mineral, clay content, exchangeable cation type, and organic matter amount for the plastic limit. Similarly, Kara et al. (2018), as a result of the study in which they examined the effect of applying gyttja as a conditioner on clayey loam textured soil with low percentage of lime content on the liquid limit (LL) and plastic limit (PL) values of the soils; they found that the organic matter $(\mathrm{OM})$, liquid limit (LL) and plastic limit (PL) values of the soil increased depending on the application dose of gyttja. This study was carried out to examine the effects of organic waste and synthetic conditioner applications on consistency limits in two soil texture with sandy loam and clayey loam in texture.

\section{MATERIALS AND METHODS}

\section{Material}

This study was carried out on soil samples taken from the Bafra application area of Samsun Ondokuz Mayıs University and the Black Sea Agricultural Research Institute's Bafra experimental field and its surface $(0-20 \mathrm{~cm})$. In the study, wheat straw (WS) and hazelnut husk $(\mathrm{HH})$ were used as organic waste, while humic acid $(\mathrm{HA})$ and polyacrylamide
(PAM) were used as synthetic conditioners. Organic wastes were used by passing through a 2 diameter sieve. These wastes and conditioners were obtained from different institutions and organizations. The wheat straw used in the study has $53.46 \%$ organic $C$ and $0.65 \%$ total $N$ content, and its $\mathrm{C} / \mathrm{N}$ value is 82.25 . The $\mathrm{pH}$ and $\mathrm{P}$ contents of wheat straw were determined as 5.69 and 2055.00 ppm, respectively. Hazelnut husk has $46.93 \%$ organic C, $1.86 \%$ total $\mathrm{N}$ content, and its $\mathrm{C} / \mathrm{N}$ ratio is 25.23 . The $\mathrm{pH}$ and $\mathrm{P}$ contents of the hazelnut husk are 6.16 and 6291.52 ppm, respectively. The applied PAM is of technical quality, and $\mathrm{HA}$ is a commercially available material containing 15\% active substance.

In the study carried out under greenhouse conditions as a pot experiment and in a split plots experimental design, organic residues $10,2 \%$ and 4\%); humic acid (0, 200 and 1000 ppm) as a synthetic conditioner; and PAM 10, 30 and 90 ppm) were used with three replications. During the experiment, the air temperature was kept between $25-30{ }^{\circ} \mathrm{C}$ with the air conditioner and irrigation was done when fifty percent of the available moisture in the pots was exhausted. Soil samples were incubated for five months and wheat plants were grown in pots after the incubation period. After the wheat plant was harvested (3 months), the relevant analyses were made on the soil samples.

\section{Methods}

The particle size distributions of soils were determined by the Bouyoucos hydrometer method (Gee et al., 1986); the soil reaction (pH) in a 1:2.5 soil-water suspension with a $\mathrm{pH}$ meter (Rowell, 1996); the electrical conductivity in soilwater suspension with a glass-electrode electrical conductivity meter (Bayraklı, 1987); the lime content of soils by measuring the volume of $\mathrm{CO}_{2}$ gas released due to hydrochloric acid treated with $\mathrm{CaCO}_{3}$ using Scheibler calcimeter (Kacar, 1994); and the organic matter contents were determined by the Walkley-Black method (Nelson and Sommers, 1983) based on the oxidation of organic carbon.

The $L L$ value of the soils was determined using the "Casagranda" instrument (Sowers, 1965). The PL value was determined according to the amount of moisture the soil had when it was formed into $3 \mathrm{~mm}$ filaments and started to disperse (Sowers, 
1965). The PI value was found by subtracting the $P L$ value from the LL value (Casagranda, 1932).

The statistical evaluation of the data obtained as a result of the research was performed using the Minitab computer package program. The Duncan test was used in multiple comparisons (Minitab, 2013).

\section{RESULTS AND DISCUSSION}

\section{Soil Properties}

Some physical and chemical properties of the soils studied are given in Table 1. As can be seen from the examination of this chart, the research soils have clayey loam and sandy loam texture. The lime content of clayey loam soil is $7.24 \%$, organic matter content is 2.09\%; the lime content of soil with sandy loam texture was determined as $17.92 \%$ and organic matter content as $1.06 \%$. Liquid limit, plastic limit and plasticity index are measured as $36.49 \%, 24.71 \%$ and $11.78 \%$ for clayey loam soil and as $22.76 \%, 16.35 \%$ and $6.41 \%$ for sandy loam soil, respectively.

Table 1. Some characteristics of the soils used in the research Çizelge 1. Araștırmada kullanılan toprakların bazı özellikleri

\begin{tabular}{|c|c|c|}
\hline & \multicolumn{2}{|c|}{ Soils } \\
\hline & OMU & BSARI \\
\hline Sand, \% & 59.42 & 23.86 \\
\hline Silt, \% & 29.88 & 42.30 \\
\hline Clay, \% & 10.70 & 33.82 \\
\hline Texture Class & SL & $\mathrm{CL}$ \\
\hline $\mathrm{pH}(1: 2.5)$ & 7.96 & 7.59 \\
\hline EC dS m-1 $(1: 2.5)$ & 0.418 & 0.425 \\
\hline $\mathrm{CaCO}_{3}, \%$ & 17.92 & 7.24 \\
\hline $\mathrm{OM}, \%$ & 1.06 & 2.09 \\
\hline \multicolumn{3}{|l|}{ Consistency limits (PW) } \\
\hline Liquid limit (LL), \% & 22.76 & 36.49 \\
\hline Plastic limit (PL), \% & 16.35 & 24.71 \\
\hline Plasticity index (PI), \% & 6.41 & 11.78 \\
\hline \multicolumn{3}{|c|}{$\begin{array}{l}\mathrm{CaCO}_{3} \text { : lime content, OM: organic matter content, EC: electrical } \\
\text { conductivity, PW: Percentage weight OMU: Ondokuz Mayls } \\
\text { University's Bafra Experimental Field, BSARI: Black Sea Agricultural } \\
\text { Research Institute's Bafra Experimental Field }\end{array}$} \\
\hline
\end{tabular}

\section{Consistency Limits}

\section{Liquid Limit (LL)}

In the study carried out under greenhouse conditions, the changes in the liquid limit values were determined after harvest in soils that were mixed and incubated with the different doses of conditioners (WS, HH, HA and PAM) and where wheat plants were grown are shown in Figure 1. As can be seen from this Figure, except for PAM applications in sandy loam textured soil, the applied conditioners provided significant improvements in liquid limit values. These increases were higher in Black Sea Agricultural Research Institute's Bafra Experimental Field with high clay (33.82\%) and organic matter content (2.09\%) and low lime content (7.24\%). The liquid limit (LL) values of the soil samples ranged from $22.76 \%$ to $44.81 \%$, and the lowest LL value was determined in the sample with sandy loam texture in the second dose application of the PAM conditioner, and the highest $L L$ value was determined in the soil with clayey loam texture and in the second dose application of wheat straw.

Soils with an LL value of less than 30\% are considered to have "low" plasticity, while those with an LL value between 30-50\% are considered to have "medium" plasticity and those with more than 50\% are considered to have "high" plasticity (Demiralay and Güresinli, 1979). Accordingly, it can be stated that Ondokuz Mayıs University's Bafra Experimental Field with sandy loam texture (LL values lower than 30\%) have low plasticity; Black Sea Agricultural Research Institute's Bafra Experimental Field with clayey loam texture (LL values between 30-50\%) have moderate plasticity.

It is determined that there are significantly negative correlations between the liquid limit values, the lime content $\left(-0.964^{* *}\right)$ and $\mathrm{pH}\left(-0.549^{* *}\right)$ of soils, while significantly positive correlations were established between and organic matter content $\left(0.714^{* *}\right)$ at the level of $1 \%$.

Deng et al. (2017) determined in their study that there are significant positive correlations

Table 2. Some chemical properties of organic wastes used in the study

Çizelge 2. Calıșmada kullanılan organik atıkların bazı kimyasal özellikleri

\begin{tabular}{cccccccc}
\hline \multirow{2}{*}{ Organic waste } & $\begin{array}{c}\mathrm{PH} \\
(1: 10)\end{array}$ & $\begin{array}{c}\mathrm{EC}(1: 10), \\
\mathrm{dS} \mathrm{m} \mathrm{m}^{-1}\end{array}$ & $\begin{array}{c}\text { OC, } \\
\%\end{array}$ & $\begin{array}{c}\text { Total N, } \\
\%\end{array}$ & C/N & $\begin{array}{c}\text { Ash, } \\
\%\end{array}$ & $\begin{array}{c}\mathrm{P}, \\
\%\end{array}$ \\
\hline WS & 5.69 & 2.848 & 53.46 & 0.65 & 82.25 & 7.84 & 0.205 \\
$\mathrm{HH}$ & 6.16 & 2.058 & 46.93 & 1.86 & 25.23 & 19.09 & 0.629 \\
\hline
\end{tabular}

WS: wheat straw, $\mathrm{HH}$ : hazelnut husk, OC: organic carbon 
between organic carbon and $\mathrm{LL}$ and PL values. Similarly, many researchers have found that there are statistically significant positive correlations between the liquid limit and plastic limit values of soils and their clay contents (Aksakal et al., 2013; Spagnoli et al., 2018) and organic matter contents (Canpolat and Öztaș, 1997; Gülser and Candemir, 2006)

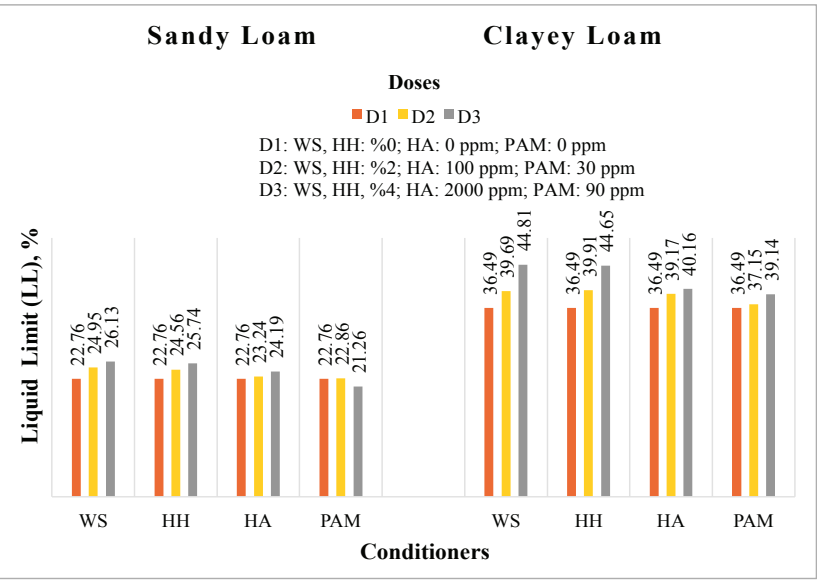

Figure 1. Changes in the liquid limit values due to applications compared to control (WS: wheat straw, HH: hazelnut husk, HA: humic acid, PAM: polyacrylamide)

Șekil 1. Uygulamaların likit limit değerlerinde kontrole göre meydana getirdiği değișimler

According to the results of variance analysis, the effect of the mean squares of soils, conditioner types and application doses on the change in the liquid limit values of the study soils $(p<0.01)$ was found to be significant. The Duncan multiple comparison test results, which were conducted to examine the conditioner types and the effectiveness of the applied doses, are given in Table 3.

As can be understood from the examination of these data, the effectiveness of hazelnut husk and wheat straw on the $L L$ value of the soils is the highest, and the effectiveness of the PAM conditioner is the least; and it was determined that the LL values increased with the higher dose levels.

\section{Plastic limit (PL)}

In the study carried out under greenhouse conditions, the changes in the plastic limit values determined after harvest in soils that were mixed and incubated with different doses of conditioners (WS, HH, HA, and PAM) and where wheat plants were grown are shown in Figure 2. As can be seen from this Figure, except for PAM applications in sandy loam textured soil, the applied conditioners provided significant improvements in plastic limit values. These increases were higher in the samples from Ondokuz Mayıs University's Bafra Experimental Field with high sand (59.41\%) and lime content (17.92\%) and low organic matter content $(1.06 \%)$. PL values ranged between 15.01-30.19\%, with the lowest PL value recorded in the soil with sandy loam texture and in the second dose application of the PAM conditioner, and the highest PL value recorded in the second dose application of hazelnut husk in the soil with clayey loam texture.

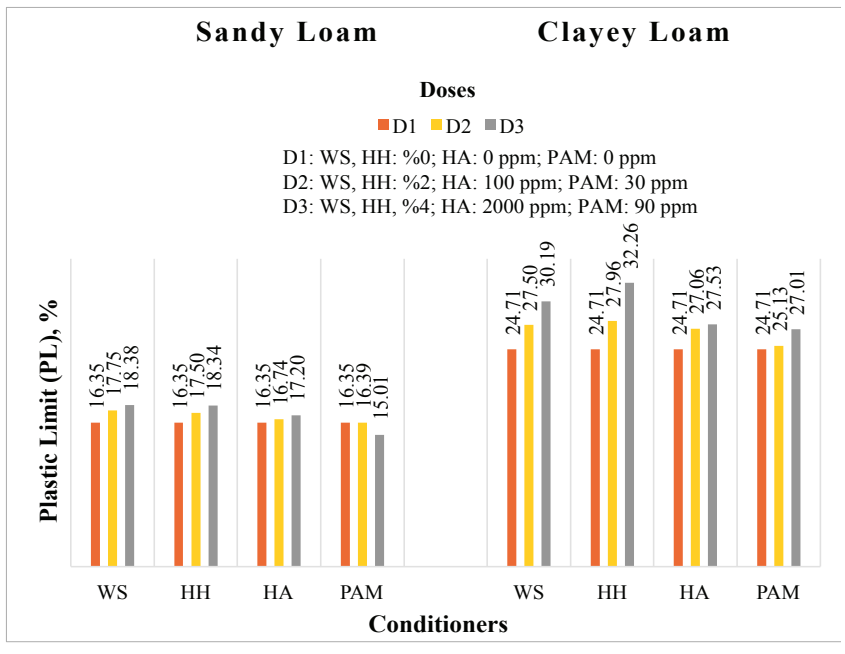

Figure 2. Changes in the plastic limit values due to applications compared to control (WS: wheat straw, HH: hazelnut husk, HA: humic acid, PAM: polyacrylamide)

Șekil 2. Uygulamaların plastic limit değerlerinde kontrole göre meydana getirdiği değișimler

Table 3. Duncan test results on the effects of soils mixed with different doses of conditioners on liquid limit values Çizelge 3. Farklı dozlarda düzenleyici karıștırılan toprakların likit limit değerleri üzerine etkilerine ilișkin Duncan testi sonuçları

\begin{tabular}{lcccc}
\hline Conditioners & WS & $H \mathrm{H}$ & $\mathrm{HA}$ & PAM \\
Liquid Limit (LL), \% & $32.47^{\mathrm{a}}$ & $32.17^{\mathrm{a}}$ & $31.00^{\mathrm{b}}$ & $29.95^{\mathrm{c}}$ \\
\hline Doses & $\mathrm{D} 1$ & $\mathrm{D} 2$ & $\mathrm{D} 3$ & $33.26^{\mathrm{a}}$ \\
Liquid Limit (LL), \% & $29.63^{\mathrm{c}}$ & $31.44^{\mathrm{b}}$ & 3 . & \\
\hline
\end{tabular}

(WS: wheat straw, HH: hazelnut husk, HA: humic acid, PAM: polyacrylamide (D1: WS, HH: 0\%; HA: 0 ppm; PAM: 0 ppm, D2: WS, HH: 2\%; HA: 100 ppm; PAM: 30 ppm, D3: WS, HH, 4; HA: 2000 ppm; PAM: 90 ppm)l 
Table 4. Duncan test results on the effects of soils mixed with different doses of conditioners on plastic limit values

Çizelge 4. Farklı dozlarda düzenleyici karıștırılan toprakların plastik limit değerleri üzerine etkilerine ilișkin Duncan testi sonuçları

\begin{tabular}{|c|c|c|c|c|}
\hline Conditioners & WS & $\mathrm{HH}$ & $\mathrm{HA}$ & PAM \\
\hline Plastic limit (PL), \% & $22.48^{b}$ & $22.86^{a}$ & $21.60^{c}$ & $20.77^{d}$ \\
\hline Doses & D1 & D2 & D3 & \\
\hline Plastic limit (PL), \% & $20.53^{c}$ & $22.00^{\mathrm{b}}$ & $23.24^{a}$ & \\
\hline
\end{tabular}

Significantly negative correlations were detected at the level of $1 \%$ between PL values and lime content $\left(-0.947^{* *}\right)$ and $\mathrm{pH}\left(-0.528^{* *}\right)$ values of soils, while significantly positive correlations were found at the level of $1 \%$ between the organic matter content $\left(0.734^{* *}\right)$ and PL values.

According to a study, Ou et al. (2014) stated that there was a statistically significant increase in plastic limit values with the application of different doses of rice husk ash to the soil, while Stanchi et al. (2015) stated that the plastic limit values in the upper soil horizons were higher than the lower horizons, and this situation was related to the organic matter content in the surface layer.

According to the results of variance analysis, the effect of the mean squares of soils, conditioner types, and application doses on the change in the $P L$ value of the study soils $(p<0.01)$ was found to be significant. The Duncan multiple comparison test results, which were conducted to examine the conditioner types and the effectiveness of the applied doses, are given in Table 4.

As can be understood from the examination of these data, the effectiveness of $\mathrm{HH}$ on the PL value of the soils is the highest, and the effectiveness of the PAM conditioner is the least; and it was determined that the PL values increased with the higher dose levels.

\section{Plasticity index (PI)}

In the study carried out under greenhouse conditions, the changes in the PI values determined after harvest in soils that were mixed and incubated with different doses of conditioner (WS, HH, HA and PAM) and where wheat plants were grown are shown in Figure 3. As can be understood from this Figure, except for PAM applications in sandy loam textured soil, the applied conditioners provided significant improvements in PI values. Such increases were higher in the samples from Black Sea Agricultural Research Institute's Bafra
Experimental Field with high sand (33.82\%) and organic matter content (2.09\%) and low lime content (7.24\%). PI values ranged between 6.25 and $14.48 \%$, with the lowest PI value seen in the soil with sandy loam texture and in the second dose application of the PAM conditioner, and the highest PI value seen in the second dose application of wheat straw in the soil with clayey loam texture.

The $\mathrm{Pl}$ index value is used as a parameter in the evaluation of tillage time. A high PI value indicates that the risk of sludge formation will increase when the soils are cultivated (Demiralay and Güresinli, 1979; Mueller et al., 2003). Gülser and Candemir (2006) examined the PI values of the soil series in the Ondokuz Mayıs University Campus, and found that the PI values increased with the order of Aksu < Kurupelit < Müzmüllü $<$ Oyumca < Incesu; they stated that the risk of sludge formation during tillage is higher in the Incesu and Oyumca series than in the other series. In light of such findings and considering the PI values of the soils in this study, it can be stated that the risk of sludge formation during tillage is higher in Black Sea Agricultural Research Institute's Bafra Experimental Field with high clay content than in Ondokuz Mayıs University's Bafra Experimental Field with high sand content.

Significantly negative correlations were detected at the level of $1 \%$ between PI values and lime content $\left(-0.973^{* *}\right)$ and $\mathrm{pH}\left(-0.575^{* *}\right)$ values of soils, while significantly positive correlations were found at the level of $1 \%$ between such values and the organic matter content $\left(0.657^{* *}\right)$. Considering relevant studies, Rezaee et al. (2019) examined swelling shrinkage characteristics and plasticity indices in paddy fields, and stated that clay content, cation exchange capacity, organic carbon and saturated water content have significant effects on the value of Atterberg limits in cultivated soils. 
Demir et al. (2012) found significant positive relationships between liquid limit, plastic limit and plasticity index and clay content, organic matter and lime content in the study they carried out to examine the relationship between soil consistency limits and some soil properties depending on land use in the Uğrak Basin, and stated that there was no significant relationship with silt, sand, $\mathrm{pH}$ and EC values.

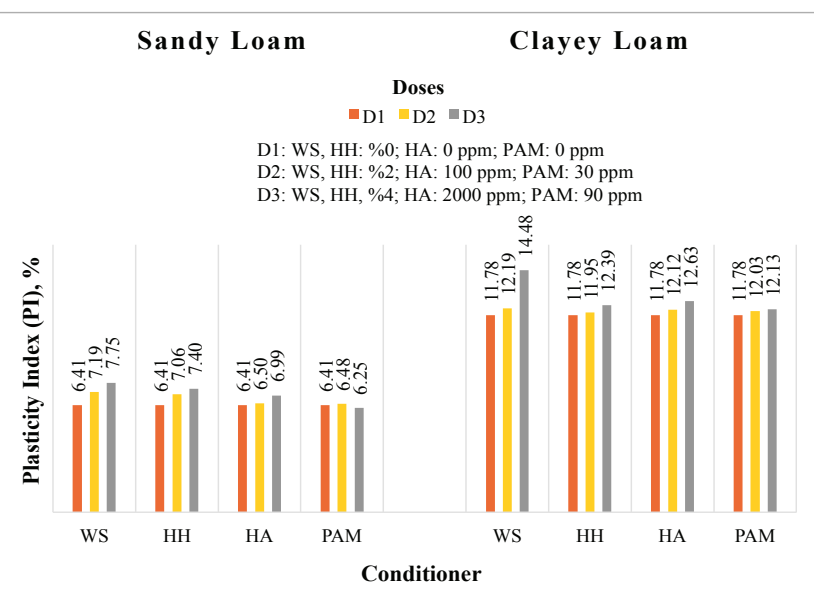

Figure 3. Changes in the plasticity index values due to applications compared to control (WS: wheat straw, $\mathrm{HH}$ : hazelnut husk, HA: humic acid, PAM: polyacrylamide)

Sekil 3. Uygulamaların plastiklik indeksi değerlerinde kontrole göre meydana getirdiği değișimler

According to the results of variance analysis, the effect of the mean squares of soils, conditioner types and application doses on the change in the plasticity index value of the study soils $(p<0.01)$ was found to be significant. The Duncan multiple comparison test results, which were conducted to examine the conditioner types and the effectiveness of the applied doses, are given in Table 5 .

As can be seen from the examination of these findings, the effectiveness of WS on the plasticity index value of the soils is the highest, and the effectiveness of the PAM conditioner is the least; and it was determined that the PI values increased with the higher dose levels.

\section{CONCLUSIONS}

In this study, in which changes in the consistency limits were examined with the addition of WS, $\mathrm{HH}, \mathrm{HA}$ and PAM in clayey loam and sandy loam textured soil samples; it has been observed that the aforementioned conditioners added to the soils cause increases in the LL, PL and PI values, but the effect of the PAM conditioner on the consistency limits of the sandy loam in texture soils remained low level. This is probably related to the nature of PAM, the effect of soil texture and the incubation and cultivation process. It has been determined that the effectiveness of organic and synthetic conditioners used on the consistency limits are listed as WS $>\mathrm{HH}>\mathrm{HA}>$ PAM. It is seen that organic wastes are more effective than synthetic conditioners on consistency limits. This is probably associated with the chemical structure of hazelnut husk and wheat straw and disintegration time ( $\mathrm{C} / \mathrm{N}$ ratio). And the fact that the conditioners were more effective in clay textured soils is probably due to the length of the process (incubation and cultivation) and the decelerated texture disintegration and aeration process. On the other hand, statistically significant positive correlations were found between soil consistency limits and organic matter content, while significant negative correlations were established with lime and $\mathrm{pH}$ values. It was determined that the effectiveness of conditioners depends on their own characteristics, and the texture, lime and organic matter content of soils, as well as on the application dose.

\section{REFERENCES}

Aksakal EL, Angin I, Oztas T (2013). Effects of diatomite on soil consistency limits and soil compactibility. Catena, 101: 157-163. doi: 10.1016/j.catena.2012.09.001

Bayraklı F (1987). Toprak ve Bitki Analizleri. Ondokuz Mayıs Üniversitesi Yayınları, Yayın No: 17, Samsun.

Canbolat MY, Öztaș T (1997). Toprağın kıvam limitleri üzerine etki eden bazı faktörler ve kıvam limitlerinin tarımsal yönden değerlendirilmesi. Atatürk Üniversitesi Ziraat Fakültesi Dergisi. 28 (1): 120-129

Table 5. Duncan test results on the effects of soils mixed with different doses of conditioners on plasticity index values Çizelge 5. Farklı dozlarda düzenleyici karıștırılan toprakların plastiklik indeksi üzerine etkilerine ilișkin Duncan testi sonuçları

\begin{tabular}{ccccc}
\hline Conditioners & WS & $H H$ & $H A$ & PAM \\
Plasticity index (PI), \% & $9.97^{\mathrm{a}}$ & $9.50^{\mathrm{b}}$ & $9.40^{\mathrm{b}}$ & $9.18^{\mathrm{c}}$ \\
\hline Doses & $\mathrm{D} 1$ & $\mathrm{D} 2$ & $\mathrm{D} 3$ & \\
Plasticity index (PI), \% & $9.10^{\mathrm{c}}$ & $9.44^{\mathrm{b}}$ & $10.00^{\mathrm{a}}$ & \\
\hline
\end{tabular}

(WS: wheat straw, HH: hazelnut husk, HA: humic acid, PAM: polyacrylamide (D1: WS, HH: 0\%; HA: 0 ppm; PAM: 0 ppm, D2: WS, HH: 2\%; HA: 100 ppm; PAM: 30 ppm, D3: WS, HH, 4; HA: 2000 ppm; PAM: 90 ppm)l 
Casagrande A (1932). Research on the Atterberg limits of soils. Public roads, 13 (8): 121-136.

Demir S, Kılıç K, Aydın M (2012). Farklı Kullanım Altındaki Toprakların Kıvam Limitleriyle Bazı Toprak Özellikleri Arasındaki İlișki.

Demiralay i̇, Güresinli YZ (1979). Erzurum Ovası topraklarının kıvam limitleri ve sıkıșabilirliği üzerinde bir araștırma. Atatürk Üniversitesi Ziraat Fakültesi Dergisi, 10: 7793.

Deng Y, Cai C, Xia D, Ding S, Chen J, Wang T (2017). Soil Atterberg limits of different weathering profiles of the collapsing gullies in the hilly granitic region of southern China. Solid Earth. 8: 499-513. doi: 10.5194/se-8-499-2017.

Dexter AR, Bird NRA (2001). Methods for predicting the optimum and the range of soil water contents for tillage based on the water retention curve. Soil and Tillage Research, 57 (4): 203-212.

Farrar DM, Coleman JD (1967). The correlation of surface area with other properties of nineteen British clay soils. Journal of Soil Science, 18(1): 118-124. doi:10.1111/j.1365-2389.1967.tb01493.x

Gee GW, Bauder JW, Klute A (1986). Methods of Soil Analysis, Part 1. Physical and Mineralogical Methods. Soil Science Society of America, American Society of Agronomy.

Gülser C, Candemir F (2006). Ondokuz Mayıs Üniversitesi Kurupelit Kampüs Topraklarının Bazı Mekaniksel Özellikleri ve İșlenebilirlikleri. Anadolu Tarım Bilimleri Dergisi, 21 (2), 213217.

Kacar B (1994). Bitki ve Toprağın Kimyasal Analizleri, III. Toprak Analizleri. Ankara Üniversitesi Ziraat Fakültesi Eğitim Araștırma ve Geliștirme Vakfı Yayınları, No.3, Ankara.

Kara Z, Yakupoğlu T, Sesveren S, Solak S, Saltalı K (2018). Applied to agriculture soil gyttja: effect on the Atterberg limits and some physical parameters. In 1 th International GAP Agriculture and Livestock Congress, Șanlıurfa/Turkey, Proceedings Book (pp. 441-445).

Minitab, Inc. 2013. Minitab 17.1 (Computer Software). State College, PA: Minitab, Inc.
Mueller L, Schindler U, Fausey NR, Lal R (2003). Comparison of methods for estimating maximum soil water content for optimum workability. Soil and Tillage Research, 72 (1): 9-20. doi:10.1016/s0167-1987(03)00046-1.

Nelson DW, Sommers L (1983). Total carbon, organic carbon and organic matter. Methods of soil analysis: Part 2 chemical and microbiological properties, 9: 539-579.

Odell RT, Thornburn TH, McKenzie $\sqcup$ (1960). Relationships of Atterberg limits to some other properties of Illinois soils. Soil Science Society of America Journal, 24(4): 297-300. doi: 10.2136/sssaj1960.03615995002.

Qu J, Li B, Wei T, Li C, Liu B (2014). Effects of rice-husk ash on soil consistency and compactibility, Catena. 122,:54-60. doi: 10.1016/j.catena.2014.05.016.

Rezaee L, Moosavi AA, Davatgar N, Sepaskhah AR (2019). Shrinkage-swelling characteristics and plasticity indices of paddy soils: spatial variability and their influential parameters. Archives of Agronomy and Soil Science, 1-21. DOI: 10.1080/03650340.2019.1706169.

Rowell DL (1996). Soil Science: Methods and Applications. Wesley Longman Ltd, Harlow.

Sowers GF (1965). Consistency. Methods of Soil Analysis, Part 1. Physical and Mineralogical Properties. Including Statistics of Measurement and Sampling, 9: 391-399.

Spagnoli G, Sridharan A, Oreste P, Bellato D, Di Matteo $L$ (2018). Statistical variability of the correlation plasticity index versus liquid limit for smectite and kaolinite Applied. Clay Science, 156: 152-159. https://doi.org/10.1016/j. clay.2018.02.001

Stanchi S, D'Amico M, Zanini E, Freppaz M (2015). Liquid and plastic limits of mountain soils as a function of the soil and horizon type. Catena, 135: 114-121. doi: 10.1016/j. catena.2015.07.021.

Yakupoğlu T, Özdemir N (2006). Erozyona Uğramıș Topraklarda Organik Atık Uygulamalarının Bazı Mekaniksel Özelliklere Etkisi. Anadolu Tarım Bilimleri Dergisi, 21 (2): 173178. 